\title{
In Vivo Proteolysis of Serum Insulin-like Growth Factor (IGF) Binding Protein-3 Results in Increased Availability of IGF to Target Cells
}

\author{
Christiane Blat, * Jacqueline Villaudy, ${ }^{*}$ and Michel Binoux * \\ *Institut National de la Santé et de la Recherche Médicale, Unité de Recherches sur la Régulation de la Croissance (U.142), Hôpital \\ Saint Antoine; and ${ }^{\ddagger}$ Institut Curie, Paris, France.
}

\begin{abstract}
IGF Binding Protein-3 (IGFBP-3), the major IGF carrier in the blood, undergoes limited proteolysis which reduces its affinity for IGFs, thus facilitating dissociation. The functional effects of this at the cellular level were studied by comparing two serum pools, one from healthy adults, one from women during late pregnancy when IGFBP-3 proteolysis is increased. Sera were mixed to yield identical IGF-I and IGF-II concentrations in the two pools. Western ligand and immunoblotting gave the characteristic IGFBP patterns for the two types of serum. Both pools dose-dependently stimulated DNA synthesis in cultured chick embryo fibroblasts. Stimulation by pregnancy serum was twice that by normal serum at $0.05-0.2 \%$ concentrations $(P<0.001)$. In the presence of excess monoclonal antiIGF-I and -II antibodies, stimulation by both (0.1-0.2\%) pools was 70-80\% reduced and residual stimulation was similar. Addition of recombinant human (rh)IGFBP-3 dose-dependently depressed both pools' activity, more so for normal serum at 25 and $50 \mathrm{ng} / \mathrm{ml}$, equally for each at $100 \mathrm{ng} / \mathrm{ml}$. At the latter concentration, slight proteolysis of the rhIGFBP-3 was detectable in the presence of $0.2 \%$ pregnancy serum, but at $25 \mathrm{ng} / \mathrm{ml}$, proteolysis was absent. These results suggest that IGFs are released more readily from pregnancy serum, accounting for the weaker inhibitory effect of low rhIGFBP-3 concentrations. For identical IGF concentrations, pregnancy serum's greater biological activity therefore reflects greater IGF availability to the cells. This study demonstrates the functional consequences at cellular level of serum IGFBP-3 proteolysis, underlining its significance in regulating serum IGF bioavailability. (J. Clin. Invest. 1994. 2286-2290.) Key words: proteases • fibroblasts • DNA synthesis
\end{abstract}

\section{Introduction}

The insulin-like growth factors, IGF-I and IGF-II, are produced in many tissues, together with their specific, high-affinity binding proteins (IGFBPs). ${ }^{1}$ The liver, however, is the major

Address correspondence to M. Binoux, INSERM U. 142, Hôpital Saint Antoine, 184 rue du Faubourg St. Antoine, 75571 Paris Cedex 12, France.

Received for publication 21 September 1993 and in revised form 7 December 1993.

1. Abbreviations used in this paper: CEF, chick embryo fibroblast; IGFBP, IGF binding protein; rh, recombinant human.

J. Clin. Invest.

(c) The American Society for Clinical Investigation, Inc. $0021-9738 / 94 / 05 / 2286 / 05 \quad \$ 2.00$

Volume 93, May 1994, 2286-2290 source of IGFs and IGFBPs in the bloodstream, which means their action is both paracrine/autocrine and endocrine $(1,2)$. The six known species of binding protein (IGFBP-1-6) modulate, generally by inhibiting, but sometimes by enhancing, the action of the IGFs on their target cells, although the mechanisms involved remain to be elucidated $(3,4)$. In the blood, $\sim 20 \%$ of the IGFs are carried by IGFBPs as $\sim 40-\mathrm{kD}$ binary complexes and $\sim 80 \%$ as $140-\mathrm{kD}$ ternary complexes where IGF-I- or -II-IGFBP complexes are associated with an 85-kD subunit (5). The binary complexes are capable of crossing the capillary endothelium, but the ternary complexes are not, which markedly increases the half-lives of the IGFs. Thus, the ternary complexes constitute their circulating reserves and regulate their availability to the tissues $(6,7)$.

Recent studies have suggested that the IGFs' bioavailability may be enhanced both in the bloodstream and locally as a result of partial proteolysis by serine proteases of certain IGFBPs, particularly IGFBP-3 (8-10). IGFBP-3 proteolysis is detectable in the normal state $(11,12)$, but is considerably increased during gestation $(8,9)$ and in some pathological conditions $(13,14)$ when the needs of cell growth and metabolism are intensified. Nevertheless, no proof has as yet been provided that serum IGF bioavailability is increased as a direct result of IGFBP-3 proteolysis. This then was the aim of the present work. The model used was chick embryo fibroblasts in culture, which we had previously shown were particularly sensitive to the mitogenic potency of IGFs and the inhibitory action of IGFBPs (15-17). Our data show that in serum IGFs are more readily released from proteolysed than from intact IGFBP, rendering the IGFs more available to the cells, a measure of which is their stimulatory effect on DNA synthesis.

\section{Methods}

\section{Serum pools}

Serum pools were made up from samples taken from six healthy adults (four men, two women) and six women in the last trimester of pregnancy. The sera had been selected on the basis of total concentrations of IGF-I and IGF-II measured after acidic gel filtration and the electrophoretic profiles of IGFBPs analyzed by Western ligand blotting, according to techniques used routinely in our laboratory $(18,19)$. The sera were mixed in proportions to yield identical concentrations of IGF in each pool, i.e., $250 \mathrm{ng} / \mathrm{ml} \mathrm{IGF-I} \mathrm{and} 1,450 \mathrm{ng} / \mathrm{ml} \mathrm{IGF-II.}$

\section{IGF and IGFBP-3 preparations}

Recombinant human (rh) IGF-I and IGF-II were generous gifts from Ciba Geigy Ltd. (Basel, Switzerland) and nonglycosylated rhIGFBP-3 from Celtrix Pharmaceuticals, Inc. (Santa Clara, CA).

\section{Monoclonal anti-IGF-I and IGF-II antibodies}

These were purchased from Upstate Biochemical Corp. (Lake Placid, NY). According to the manufacturer, the anti-IGF-I antibody, raised in the mouse with purified natural hIGF-I, is specific for both IGF-I 
and IGF-II of human, rat, and mouse origin and has some cross-reactivity with chicken IGF-I and IGF-II. The anti-IGF-II antibody, raised in the mouse with partially purified rat IGF-II, is specific for IGF-II of rat and human origin and has $<10 \%$ cross-reactivity with hIGF-I.

\section{Cell culture}

Cultures of chick embryo fibroblasts (CEF) were prepared from trypsinized 10-d-old brown Leghorn chick embryos. Cells were grown in modified Eagle's medium supplemented with antibiotics and 5\% newborn calf serum in a $\mathrm{CO}_{2}$ incubator at $37^{\circ} \mathrm{C}$, as previously described (20).

Assay of the stimulatory activity of human serum. Secondary cultures of CEF were seeded in 96 -well plates at $2.5 \times 10^{5}$ cells per $\mathrm{cm}^{2}$ in medium with $5 \%$ new-born calf serum. After $5 \mathrm{~h}$, the monolayers were washed and then maintained in serum-free medium for $42 \mathrm{~h}$. Thereafter, this medium was discarded and replaced by fresh medium with or without (controls) the appropriate concentrations of either human serum pool in a volume of $130 \mu \mathrm{l}$ per well (time zero). Culture was continued for $24 \mathrm{~h}$ and DNA synthesis measured, as previously described $(21)$, by labeling the cells with $\left[{ }^{14} \mathrm{C}\right]$ thymidine added $(0.025$ $\mu \mathrm{Ci} /$ well) at $5 \mathrm{~h}$.

In this model, rhIGF-I and IGF-II induce the same maximal stimulation, but twice as much IGF-I $(40 \mathrm{ng} / \mathrm{ml})$ is required as IGF-II $(20$ $\mathrm{ng} / \mathrm{ml}$ ). This maximal stimulation is the same as that induced by $0.4 \%$ human serum (unpublished results).

Assay of IGF neutralization by antibodies. A mixture of anti-IGF-I and anti-IGF-II monoclonal antibodies was pre-incubated at $4^{\circ} \mathrm{C}$ for $22 \mathrm{~h}$ at a concentration of $10 \mu \mathrm{g} / \mathrm{ml}$ in $130 \mu \mathrm{l}$ fresh medium with or without human serum, then added to $\mathrm{CEF}$ at $0 \mathrm{~h}$, under the same culture conditions as described above. During the subsequent $24 \mathrm{~h}$ of culture, cells were labeled with $\left[{ }^{14} \mathrm{C}\right]$ thymidine.

Preliminary assays had shown that at this concentration anti-IGF-I inhibited $100 \%$ of the stimulation by $20 \mathrm{ng} / \mathrm{ml}$ rhIGF-I and anti-IGFII inhibited $100 \%$ of that by $10 \mathrm{ng} / \mathrm{ml}$ rhIGF-II (not shown).

Assay of rhIGFBP-3 activity. Appropriate concentrations of rhIGFBP-3 were pre-incubated at $4^{\circ} \mathrm{C}$ for $22 \mathrm{~h}$ in fresh medium with or without human serum, then added to CEF under the same culture conditions as for the IGF neutralization by antibodies assay.

Preliminary assays had shown that, like native IGFBP-3 (15), rhIGFBP-3 dose-dependently inhibits IGF-induced stimulation. Total inhibition was obtained with $100 \mathrm{ng} / \mathrm{ml} \mathrm{IGFBP-3}$ for $15 \mathrm{ng} / \mathrm{ml} \mathrm{IGF-I}$ or IGF-II, i.e., a molar ratio of 1.77 (not shown).

Preparation of culture medium samples for Western blotting. Preincubation and culture conditions were the same as above, except that the CEF were seeded in 24 -well plates ( $500 \mu \mathrm{l}$ per well $)$. $1.5-\mathrm{ml}$ samples of medium with or without human serum and/or rhIGFBP-3 were taken at 0 and $24 \mathrm{~h}$ (pooled media from three wells) and $1 \mathrm{mM}$ PMSF immediately added before 10 -fold concentration by ultrafiltration on Centricon 10 (W. R. Grace \& Co., Amicon Division, Danvers, MA ) in preparation for SDS-PAGE. Each sample analyzed represented $0.5 \mathrm{ml}$ equivalent of culture medium.

\section{Western ligand- and immunoblotting}

Electrophoretic analysis of IGFBPs was performed according to the method developed in our laboratory (19). $16 \times 18$-cm gels with the Protean II xi System (Bio-Rad Laboratories, Richmond, CA) were used for the serum samples, and $6 \times 8$-cm gels with the Mini-Protean II System for culture medium samples. The smaller gels are more convenient for low-protein samples, even if they yield poorer resolution. Electrophoretic conditions were the same for the two systems. Briefly, after migration on denaturing (SDS) $12.5 \%$ polyacrylamide gels under nonreducing conditions, the proteins were electroblotted onto nitrocellulose. IGFBPs were detected, as previously described (12), by successively incubating the same nitrocellulose sheets with $(a)$ a mixture of ${ }^{125}$ I-IGF-I and -II ( $200,000 \mathrm{cpm}$ each $)$, followed by autoradiography, (b) a specific polyclonal anti-hIGFBP-3 antibody raised in the rabbit against rhIGFBP-3 (1:1,000 dilution), and $(c)$ with anti-rabbit IgG antibody coupled to horse radish peroxidase, followed by revelation by chemiluminescence with an ECL detection system (Amersham, Aylesbury, England).

\section{Statistics}

The experiments illustrated are representative of three to five separate experiments. $t$ test was used for comparison of means.

\section{Results}

Stimulation of DNA synthesis in chick embryo fibroblasts by pregnancy and normal human sera. Fig. 1 shows the stimulation induced by the normal serum pool compared with that by the pregnancy serum pool. In each case stimulation was dose dependent at the concentrations studied. Nevertheless, pregnancy serum was between 1.4 and 1.9 times (mean: 1.6 ) more potent than normal serum at equal concentrations of $0.05,0.1$, and $0.2 \%$, and 1.3 times so at $0.4 \%(P<0.001, t$ test, paired series, five experiments).
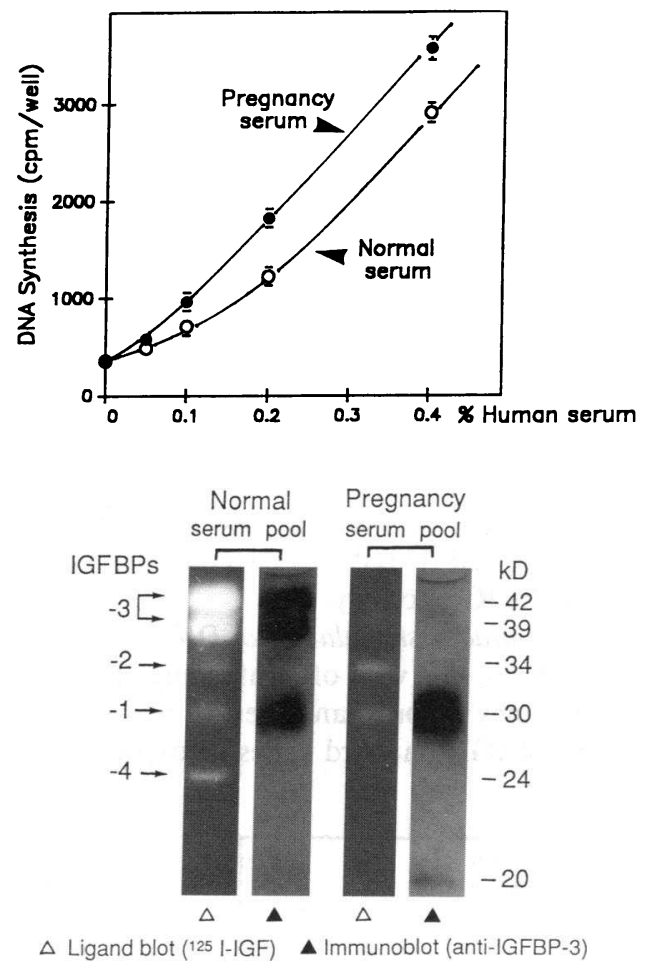

Figure 1. (Upper section) Dose-response curves of DNA synthesis in CEFs stimulated by pregnancy serum and normal human serum. Serum pools were made up from individual samples mixed to obtain equal concentrations of IGF-I ( $250 \mathrm{ng} / \mathrm{ml})$ and IGF-II $(1450 \mathrm{ng} / \mathrm{ml})$ in each pool (see Methods). The concentrations of IGF-I and IGF-II provided by pregnancy and normal serum in the culture media were therefore: 1.0 and $5.8 \mathrm{ng} / \mathrm{ml}$, respectively, for $0.4 \%$ serum; 0.75 and $4.35 \mathrm{ng} / \mathrm{ml}$ for $0.3 \%$ serum; 0.5 and $2.9 \mathrm{ng} / \mathrm{ml}$ for $0.2 \%$ serum; and 0.25 and $1.45 \mathrm{ng} / \mathrm{ml}$ for $0.1 \%$ serum. The index of DNA synthesis was the incorporation of $\left[{ }^{14} \mathrm{C}\right]$ thymidine added after $5 \mathrm{~h}$ of a 24-h incubation. Values are expressed as the mean \pm SD for quadruplicate wells. (Lower section) Western blot analysis of IGFBPs in the normal serum and pregnancy serum pools $(4 \mu \mathrm{l})$. After SDS-PAGE under nonreducing conditions and transfer to nitrocellulose, IGFBPs were detected $(\Delta)$ by incubation with a mixture of ${ }^{125}$ I-IGF-I and -II (ligand blotting) to identify IGFBPs-1, $-2,-3$ and -4 ; and ( $\triangle$ ) using a specific anti-IGFBP-3 polyclonal antibody (immunoblotting) to identify intact and proteolysed fragments of IGFBP-3 (see Methods). 
The lower portion of the figure shows the results of electrophoretic analysis of the IGFBPs in the two serum pools. With Western ligand blotting, normal serum had the two major bands corresponding to the 42-39-kD doublet for IGFBP-3 and lower-intensity bands corresponding to IGFBP-2 (34 kD), IGFBP-1 (30 kD), and IGFBP-4 (24 kD) (22). In pregnancy serum, the $42-39-\mathrm{kD}$ doublet had disappeared, which is characteristic of this physiological condition where IGFBP-3 proteolysis is particularly pronounced (8). With immunoblotting, the anti-hIGFBP-3 polyclonal antibody revealed in normal serum the 42-39-kD doublet for intact IGFBP-3 and, in addition, material migrating at $30 \mathrm{kD}$ which corresponds to the major proteolytic fragment of IGFBP-3, as seen in the normal state (12). In pregnancy serum, only the $30-\mathrm{kD}$ fragment was detectable, appearing as a broad, dense band, together with a faint band at $20 \mathrm{kD}$ corresponding to a small proteolytic fragment.

Inhibition of serum-induced stimulation of DNA synthesis by anti-IGF antibodies. To determine the IGFs' contribution to serum-induced stimulation, a second series of experiments was done comparing stimulation by 0.1 and $0.2 \%$ concentrations of the two pools with and without excess anti-IGF-I and -II antibody.

Fig. 2 shows that for cells maintained for $24 \mathrm{~h}$ in medium pre-incubated with antibody and serum there was a dramatic drop in stimulation of DNA synthesis. The percentage of inhibition was the same for normal and pregnancy serum: 72 and $70 \%$ with $0.1 \%$ serum and 80 and $79 \%$ with $0.2 \%$ serum. Residual stimulation that could not be suppressed by anti-IGF antibody was slightly, but not significantly, greater with pregnancy than with normal serum.

It could be concluded from these first series of experiments that ( $a$ ) IGFs are essential for DNA synthesis to occur, and $(b)$ that the difference in potency between the two serum pools, which were matched for IGF-I and IGF-II concentrations, could be accounted for by IGF activity.

Inhibition of serum-induced stimulation of DNA synthesis by recombinant $h I G F B P-3$. By way of confirming that the greater stimulatory potency of pregnancy serum was due to greater bioavailability of IGFs, a third series of experiments

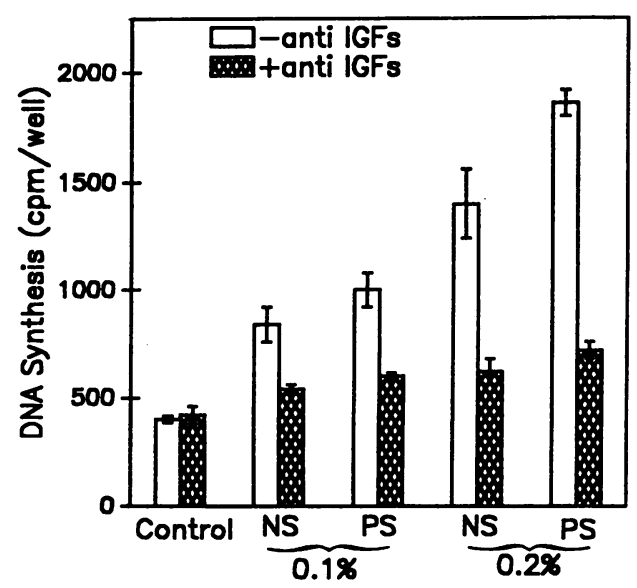

Figure 2. Stimulation of DNA synthesis in chick embryo fibroblasts by 0.1 and $0.2 \%$ of normal serum $(N S)$ and pregnancy serum $(P S)$ in the absence ( - ) and in the presence $(+)$ of a mixture of $10 \mu \mathrm{g} / \mathrm{ml}$ anti-IGF-I and $10 \mu \mathrm{g} / \mathrm{ml}$ anti-IGF-II monoclonal antibodies (see Methods). was done in which culture media with and without $0.2 \%$ normal or pregnancy serum were pre-incubated with increasing concentrations of rhIGFBP-3. In theory, if the IGFs are more readily released in pregnancy serum than in normal serum, there would be differences between the two serum pools in the dose-related inhibition of IGF activity by the added rhIGFBP-3.

Fig. $3 A$ illustrates the dose-dependent inhibitory effect of rhIGFBP-3 on serum-stimulated DNA synthesis. IGFBP-3 alone, added to medium without serum, had no effect. With high concentrations of IGFBP-3 $(100 \mathrm{ng} / \mathrm{ml})$, residual stimulation of DNA synthesis was the same for normal and pregnancy serum. With lower concentrations, the inhibitory effect was weaker on pregnancy serum than on normal serum. This is more clearly illustrated in Fig. $3 B$ where the results are expressed in terms of percentage inhibition, showing the dose-response curves for pregnancy and normal serum to be very different. Normal serum was already inhibited by $>30 \%$ by 25 $\mathrm{ng} / \mathrm{ml}$ rhIGFBP-3, whereas pregnancy serum was barely affected. At higher IGFBP-3 concentrations, the inhibition curve for normal serum flattened more than that for pregnancy serum. These results reflect the differences between the two serum pools in IGF availability to the cells. Similar results were obtained when the cells were cultured with serum and IGFBP3 added to the medium at $0 \mathrm{~h}$ without pre-incubation (not shown).

At this point it was necessary to establish whether the weaker inhibition by pregnancy serum in the presence of 50 $\mathrm{ng} / \mathrm{ml}$ and especially $25 \mathrm{ng} / \mathrm{ml}$ rhIGFBP-3 was indeed due to more extensive dissociation of the IGFs bound to proteolysed serum IGFBP-3, rather than degradation by pregnancy-associated proteases of the rhIGFBP-3 which would then become a less effective inhibitor. The culture media at the beginning ( 0 h) and end ( $24 \mathrm{~h})$ of the experiment were therefore compared by Western ligand and immunoblotting. These results are shown in Fig. $3 C$.

At $0 \mathrm{~h}$, ligand blotting revealed in the media containing added nonglycosylated rhIGFBP-3 a band at $32 \mathrm{kD}$ which corresponds to this IGFBP. The $42-39-\mathrm{kD}$ doublet for native (glycosylated) IGFBP-3 in normal serum was at the limit of detectability ( $1 \mu$ l equivalent of serum applied to the gel, as opposed to the $4 \mu \mathrm{l}$ represented in Fig. 1). With immunoblotting, which is more sensitive than ligand blotting, the antihIGFBP-3 antibody clearly revealed both the 42-39-kD doublet for intact native IGFBP-3 and the $30-\mathrm{kD}$ proteolytic fragment, the latter being the only one visible in the medium to which pregnancy serum had been added. The 32-kD band for nonglycosylated rhIGFBP-3 appeared just above the fragment.

At $24 \mathrm{~h}$ the electrophoretic profiles for the different experimental conditions were essentially the same as those at $0 \mathrm{~h}$, with, in addition, (a) a 32-kD band appearing in the conditioned media with ligand blotting, but not with immunoblotting, which corresponds to the major IGFBP secreted by chick embryo fibroblasts (and which, by its migration compared with that in human and other mammalian sera, may be IGFBP-2) and $(b)$ bands corresponding to proteins of $20 \mathrm{kD}$ and less that were detectable by the anti-hIGFBP-3 antibody in the media to which $50 \mathrm{ng} / \mathrm{ml}$ and especially $100 \mathrm{ng} / \mathrm{ml} \mathrm{rhIGFBP}-3 \mathrm{had}$ been added, but only in the presence of serum (particularly pregnancy serum), indicating slight and dose-dependent degradation of rhIGFBP-3 by serum proteases. More importantly, there was no degradation with $25 \mathrm{ng} / \mathrm{ml} \mathrm{rhIGFBP}-3$, which 

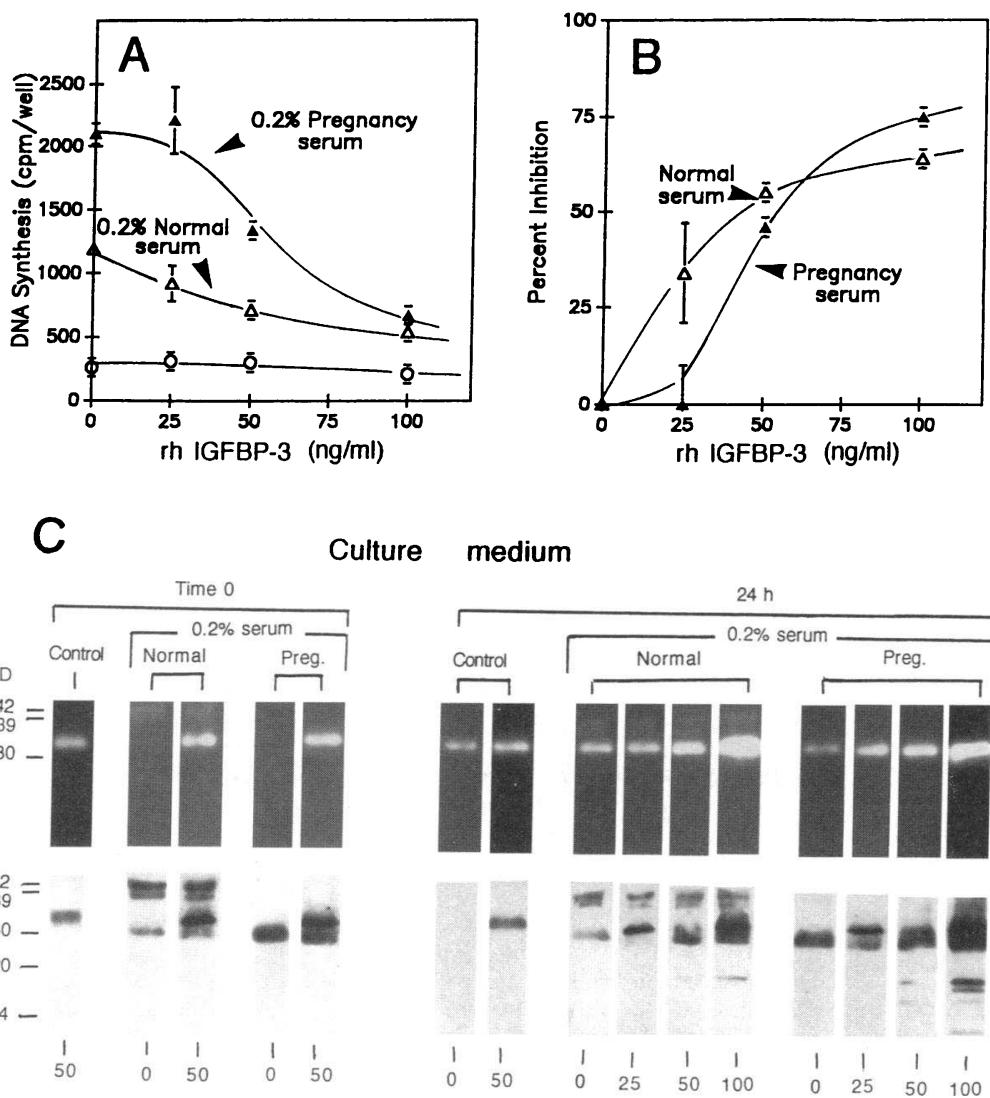

rh IGFBP-3

medium
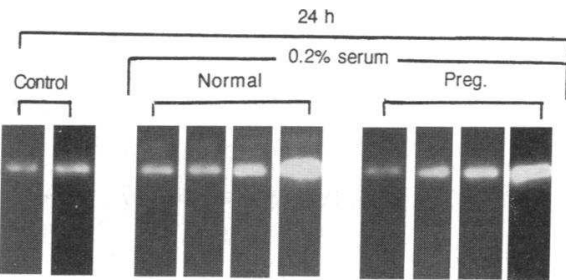

meant that the weaker inhibition by pregnancy serum at that concentration was attributable to more extensive IGF release from pregnancy than from normal serum and lesser sequestration by rhIGFBP-3.

\section{Discussion}

This study clearly shows that, at the serum concentrations used and for equal concentrations of IGF-I and IGF-II, pregnancy serum is a more potent stimulator of DNA synthesis in cultured CEFs than is normal serum. This greater potency is dependent on IGFs, since stimulation was suppressed by excess anti-IGF-I and -II antibodies and nonsuppressible residual stimulation was similar in the two types of serum.

In addition, rhIGFBP-3, which dose dependently inhibited serum-induced stimulation by both pools, reduced their biological activities to the same level at a concentration of $100 \mathrm{ng} / \mathrm{ml}$. At lower rhIGFBP-3 concentrations, pregnancy serum was subject to lesser inhibition than normal serum, which, as demonstrated by our experiments, reflects the greater availability to their target cells of the IGFs in pregnancy serum. This greater bioavailability of IGFs is a direct consequence of the limited proteolysis of IGFBP-3 by serine proteases which exist in the normal state, but whose activity is maximal during pregnancy $(8,12)$. This structural alteration of IGFBP-3 results in a loss of affinity for IGFs, which accounts for its poor detectability or lack thereof in ligand blotting (8). As seen in Fig. 1, the 42-39$\mathrm{kD}$ doublet for intact IGFBP-3 disappears in pregnancy serum and is replaced by a $30-\mathrm{kD}$ form detectable by immunoblotting and corresponding to the major proteolytic fragment of IGFBP-3.
Figure 3. ( $A$ and $B$ ) Dose-dependent inhibition by IGFBP-3 of the stimulation of DNA synthesis in CEF by $0.2 \%$ pregnancy and normal serum. The concentrations indicated of recombinant human (rh) nonglycosylated IGFBP-3 were pre-incubated at $4^{\circ} \mathrm{C}$ in fresh medium with or without human serum, then added to CEF for $24 \mathrm{~h}$ ( see Methods). Ordinate values in $A$ show $\left[{ }^{14} \mathrm{C}\right]$ thymidine incorporation at the different rhIGFBP-3 concentrations, without serum $(O-O)$ and with $0.2 \%$ pregnancy serum $(\triangle-\Delta)$ or normal serum $(\Delta-\Delta)$. In $B$, the ordinate values calculated from experimental data are expressed as percentage inhibition of DNA synthesis stimulated by $0.2 \%$ pregnancy or normal serum in the absence of IGFBP-3. $(C)$ Western blot analysis of culture media at 0 and $24 \mathrm{~h}$. Ligand blotting (upper section) reveals IGFBPs capable of binding ${ }^{125}$ I-IGF-I and -II, i.e., rhIGFBP- 3 and unaltered IGFBPs in the serum added to the medium. At $24 \mathrm{~h}$, an IGFBP secreted by the $\mathrm{CEF}$ is detectable. This can be seen in the control medium as a form with the same migration as that of rhIGFBP-3. Immunoblotting (lower section) specifcally detects human IGFBP-3; both recombinant ( 32 $\mathrm{kD})$ and the intact (42-39 $\mathrm{kD}$ ) or proteolysed ( 30 $\mathrm{kD}$ or less) forms in serum.
Serum IGFBP-3 concentrations assayed by RIA have been reported to be at least equal to or more often higher in pregnancy serum than in normal serum (23). Limited proteolysis of IGFBP-3 does not disrupt the $140-\mathrm{kD}$ complexes with which $\sim 80 \%$ of IGFs are associated in normal serum $(8,24-26)$. For this reason, some authors claim that these complexes remain functionally unchanged, particularly since they can be reconstituted from acidified pregnancy serum in the presence of the acid-labile subunit (26). However, we have shown that the structural alteration of pregnancy serum IGFBP-3, even if slight, does change it functionally in that its reduced affinity for IGFs (especially IGF-I) results in accelerated kinetics of dissociation of the IGF-IGFBP-3 complexes and redistribution of the IGFs among the circulating pools, with, in particular, increased proportions of free IGF-I (27). Since the anti-IGF-I mAb used for this study cross-reacts with IGF-II, we were unable to determine whether the increased biological activity of pregnancy serum was attributable to IGF-I and/or IGF-II.

Although our experimental conditions cannot faithfully reflect physiological conditions, since the $140-\mathrm{kD}$ complexes do not (or barely) cross the capillary barrier (6) and are therefore unlikely to be found in the cellular environment, our results do demonstrate the functional effects in cultured cells of in vivo IGFBP-3 proteolysis, in terms of increased IGF availability to the cells. The fact that the phenomenon occurs in the normal state and varies in extent with physiological (of which pregnancy is an extreme example) and metabolic conditions ( 8,9 , 11-14) underlines its significance in regulating the availability of circulating IGFs to the tissues.

Other recent reports on a variety of cell models have pointed towards the involvement of the proteolysis of IGFBP-3 
and other IGFBPs in regulating the bioavailability of locally produced IGFs. This proteolysis therefore constitutes a major mechanism in the autocrine/paracrine control of cell growth and metabolism $(10,28-31)$.

Finally, the findings described here neatly fit in with known mechanisms of activation of various growth factors $(32,33)$ and, more generally, with the role played by proteases in the control of cell proliferation $(34,35)$.

\section{Acknowledgments}

We thank Drs. A. Sommer and C. Maack (Celtrix Pharmaceuticals, Inc., Santa Clara, CA) for their generous gift of recombinant human IGFBP-3. We are indebted to Claudine Lassarre for her technical assistance.

This work was supported by the Institut National de la Santé et de la Recherche Médicale and the Association de la Recherche sur le Cancer.

\section{References}

1. Humbel, R. E. 1990. Insulin-like growth factors I and II. Eur. J. Biochem. 190:445-462.

2. Daughaday, W. H., and P. Rotwein. 1989. Insulin-like growth factors I and II. Peptide, messenger ribonucleic acid and gene structures, serum and tissue concentrations. Endocr. Rev. 10:68-91.

3. Shimasaki, S., and N. Ling. 1991. Identification and molecular characterization of insulin-like growth factor binding proteins (IGFBP-1, $-2,-3,-4,-5$ and -6 ). Prog. Growth Factor Res. 3:243-266.

4. McCusker, R. H., and D. R. Clemmons. 1992. The insulin-like growth factor binding proteins: structure and biological functions. In Insulin-like Growth Factors. Structure and Biological Functions. P. N. Schoffield, editor. Oxford University Press. 80-109.

5. Baxter, R. C., and J. L. Martin. 1989. Structure of the Mr 140,000 growth hormone-dependent insulin-like growth factor binding protein complex: determination by reconstitution and affinity labeling. Proc. Natl. Acad. Sci. USA. 86:6898-6902.

6. Binoux, M., and P. Hossenlopp. 1988. Insulin-like growth factor (IGF) and IGF-binding proteins: comparison of human serum and lymph. J. Clin. Endocrinol. \& Metab. 67:509-514.

7. Guler, H. P., J. Zapf, C. Schmid, and E. R. Froesch. 1989. Insulin-like growth factors I and II in healthy man. Estimations of half-lives and production rates. Acta Endocrinol. (Copenh). 121:753-758.

8. Hossenlopp, P., B. Segovia, C. Lassarre, M. Roghani, M. Bredon, and M. Binoux. 1990. Evidence of enzymatic degradation of insulin-like growth factor binding proteins in the " $150 \mathrm{~K}$ " complex during pregnancy. J. Clin. Endocrinol. \& Metab. 71:797-805.

9. Giudice, L. C., B. M. Farrell, H. Pham, G. Lamson, and R. G. Rosenfeld. 1990. Insulin-like growth factor binding proteins in maternal serum throughout gestation and in the puerperium: effects of a pregnancy-associated serum protease activity. J. Clin. Endocrinol. \& Metab. 71:806-816.

10. Conover, C. A. 1992. Potentiation of Insulin-like Growth Factor (IGF) action by IGF-Binding Protein-3: studies of underlying mechanism. Endocrinology. 130:3191-3199.

11. Gargosky, S. E., H. M. Pham, K. F. Wilson, F. Liu, L. C. Giudice, and R. G. Rosenfeld. 1992. Measurement and characterization of Insulin-like growth factor binding protein-3 in human biological fluids: discrepancies between radioimmunoassay and ligand blotting. Endocrinology. 131:3051-3060.

12. Lalou, C., and M. Binoux. 1993. Evidence that limited proteolysis of Insulin-like growth factor binding protein-3 (IGFBP-3) occurs in the normal state outside of the bloodstream. Regul. Pept. 48:179-188.

13. Davies, S. C., J. A. Wass, R. J. Ross, A. M. Cotterill, C. R. Buchanan, V. J. Coulson, and J. M. Holly. 1991. The induction of a specific protease for insulinlike growth factor binding protein- 3 in the circulation during severe illness. $J$. Endocrinol. 130:469-473.

14. Davenport, M. L., W. L. Isley, J. B. Pucilowska, L. Beaty Pemberton, B. Lyman, L. E. Underwood, and D. R. Clemmons. 1992. Insulin-Like Growth
Factor binding protein-3 proteolysis is induced following elective surgery. J. Clin. Endocrinol. \& Metab. 75:590-595.

15. Blat, C., J. Delbé, J. Villaudy, G. Chatelain, A. Goldé, and L. Harel. 1989. Inhibitory diffusible factor 45 bifunctional activity: as a cell growth inhibitor and as an IGF binding protein. J. Biol. Chem. 264:12449-12454.

16. Delbé, J., J. Villaudy, C. Blat, G. Desauty, A. Goldé, and L. Harel. 1990. Differences in inhibition by IDF45 (an Inhibitory Diffusible Factor) of early RNA synthesis stimulation induced by pp60 v-src and various mitogens. $J$. Cell. Physiol. 142:359-364.

17. Liu, L., J. Delbé, C. Blat, J. Zapf, and L. Harel. 1992. Insulin-like growth factor binding protein-3 (IGFBP-3), an inhibitor of serum growth factors other than IGF-I and -II. J. Cell. Physiol. 153:15-21.

18. Binoux, M., C. Lassarre, and M. Gourmelen. 1986. Specific assay for insulin-like growth factor (IGF) II using the IGF binding proteins extracted from human cerebrospinal fluid. J. Clin. Endocrinol. \& Metab. 63:1151-1155.

19. Hossenlopp, P., D. Seurin, B. Segovia-Quinson, S. Hardouin, and M. Binoux. 1986. Analysis of serum insulin-like growth factor binding proteins using Western blotting: use of the method for titration of the binding proteins and competitive binding studies. Anal. Biochem. 154:138-143.

20. Blat, C., L. Harel, J. Villaudy, and A. Goldé. 1981. Effect of transformation of chicken cells by Rous sarcoma virus on in vitro phosphorylation of nuclear non-histone proteins. Exp. Cell Res. 134:121-128.

21. Harel, L., C. Blat, and G. Chatelain. 1985. Regulation of cell proliferation inhibitory and stimulatory factors diffused by 3 T 3 cultured cells. J. Cell. Physiol. 123:139-143.

22. Binoux, M., M. Roghani, P. Hossenlopp, S. Hardouin, and M. Gourmelen. 1991. Molecular forms of human IGF binding proteins: physiological implications. Acta Endocrinol. (Copenh). 124, Suppl 2:41-47.

23. Baxter, R. C., and J. L. Martin. 1986. Radioimmunoassay of growth hormone-dependent insulin-like growth factor binding protein in human plasma. J. Clin. Invest. 78:1504-1512.

24. Davies, S. C., J. M. Holly, V. J. Coulson, A. M. Cotterill, A. F. Abdulla, P. G. Whittaker, T. Chard, and J. A. Wass. 1991. The presence of cation-dependent proteases for insulin-like growth factor binding proteins does not alter the size distribution of insulin-like growth factors in pregnancy. Clin. Endocrinol. 34:501-506.

25. Gargosky, S. E., P. C. Owens, P. E. Walton, J. A. Owens, J. S. Robinson, J. C. Wallace, and F. J. Ballard. 1991. Most of the circulating insulin-like growth factor-I and factor-II are present in the $150 \mathrm{kDa}$ complex during human pregnancy. J. Endocrinol. 131:491-497.

26. Suikkari, A. M., and R. C. Baxter. 1992. Insulin-like growth factor-binding protein-3 is functionally normal in pregnancy serum. J. Clin. Endocrinol. \& Metab. 74:177-183.

27. Lassarre, C., and M. Binoux. 1994. Insulin-like growth factor Binding Protein-3 is functionally altered in pregnancy plasma. Endocrinology. 134:12541262.

28. Fowlkes, F., and M. Freemark. 1992. Evidence for a novel insulin-like growth factor (IGF)-dependent protease regulating IGF-binding-protein-4 in dermal fibroblasts. Endocrinology. 131:2071-2076.

29. Koutsilieris, M., and C. Polychronakos. 1992. Proteinolytic activity against IGF-binding proteins involved in the paracrine interactions between prostate adenocarcinoma cells and osteoblasts. Anticancer Res. 12:905-910.

30. Conover, C., M. C. Kiefer, and J. Zapf. 1993. Posttranslational regulation of insulin-like growth factor binding protein-4 in normal and transformed human fibroblasts-insulin-like growth factor dependence and biological studies. $J$. Clin. Invest. 91:1129-1137.

31. Campbell, P. G., J. F. Novak, K. Wines, and P. E. Walton. 1993. Localization of plasmin activity on osteosarcoma cells: cell surface proteolysis of Insulinlike Growth Factor Binding Proteins. Growth Regul. 3:95-98.

32. Bashkin, P., S. Doctrow, M. Klagsbrun, C. M. Svahn, J. Folkman, and I. Vlodavsky. 1989. Basic Fibroblast growth factor binds to subendothelial extracellular matrix and is released by heparitinase and heparin-like molecules. Biochemistry. 28:1737-1743.

33. Sato, Y., and D. B. Rifkin. 1989. Inhibition of endothelial cell movement by pericytes and smooth muscle cells: activation of a latent Transforming growth factor- $\beta 1$-like molecule by plasmin during co-culture. J. Cell Biol. 109:309-315.

34. Cunningham, D. D. 1981. Proteases as growth factors. In Handbook of Experimental Pharmacology, Tissue Growth Factors. R. Baserga, editor. Springer-Verlag, Heidelberg, Germany. 229-248.

35. Mignatti, P., E. Robbins, and D. B. Rifkin. 1986. Tumor invasion through the human amniotic membrane: requirement for a proteinase cascade. Cell. 47:487-498. 